http://dx.doi.org/10.12775/szhf.2021.023

\author{
Damian Michat WinczewsKi \\ Uniwersytet Marit Curie-SkŁodowskiej w Lublinie \\ E-MAIL: DAMIAN.WINCZEWSKI@GMAIL.COM \\ ORCID: 0000-0003-0809-4817
}

\title{
Scjentystyczna szkoła filozofii marksistowskiej w Polsce i rewizjonizm
}

\begin{abstract}
The aim of the article was to discuss scientist Marxist philosophy in Poland as one of the varieties of the broad trend of revisionism in Marxism. Its main goals and assumptions can be read as a modernization of dialectical materialism in the spirit of critical realism and critical rationalism. The achievements of Scientist Marxism were compared with the perspective of Humanist Marxism, considered in Poland to be the main version of Marxist revisionism, and also with assumptions of Poznań Methodological School, which is considered as local version of Analytical Marxism.
\end{abstract}

Keywords: Marxism, scientism, revisionism, dialectical materialism, methodology of science

\section{Wstęp}

Historia filozofii marksistowskiej w Polsce, jej rozwoju, głównych problemów i nurtów została niemal zapomniana - po 1989 roku pisali o niej 
najczęściej tylko ci, którzy sami ją wcześniej współtworzyli i nie chcieli wyrzec się swego dorobku. Wśród większości wypowiadających się na ten temat badaczy przeważają jednak dość ogólne oceny tego okresu dzielące go na okres stalinowski i poststalinowski ${ }^{1}$.

Zwykło się powszechnie przyjmować, że czas do 1956 roku był okresem dominacji stalinowskiej interpretacji „marksizmu-leninizmu”, czyli wulgarnej, skodyfikowanej w latach trzydziestych w Związku Radzieckim, oficjalnej, instytucjonalnie zależnej od celów politycznych Partii „filozofii”, stanowiącej wyciąg rzekomo uniwersalnych i naukowych „prawd” zawartych w dziełach klasyków marksizmu podzielonych na dwa działy - materializm dialektyczny i materializm historyczny. Następnie w wyniku poluzowania nacisków ideologicznych zaczęły powstawać nowe, rewizjonistyczne interpretacje marksizmu, w ramach których, odchodząc od oficjalnej ortodoksji, starano się podejmować problematykę filozofii marksistowskiej w duchu zbliżonym do marksizmu zachodniego. Z tego względu, gdy mowa o powojennej filozofii marksistowskiej w Polsce, zazwyczaj wymienia się jej dwa główne nurty orientację humanistyczno-antropologiczną oraz orientację analityczną.

Najbardziej zapomnianą tradycją historii marksistowskiej refleksji w Polsce wydaje się jej odmiana scjentystyczna. Próżno szukać o niej wzmianek we współczesnych opracowaniach. Wyjątkiem jest wyważona opinia Andrzeja Walickiego, który ocenił, że w porównaniu $\mathrm{z}$ dogmatyzmem panującym w krajach ościennych scjentystyczny marksizm w PRL można pozytywnie zaklasyfikować jako odmianę "rewizjonizmu”. Z drugiej strony przywiązanie do intuicji klasyków (zapewne autor miał na myśli Engelsa i Lenina) hamować miało twórczy rozwój teorii nauki i stanowić nieodpowiednią rekomendację dla zachodnich czytelników². Warto tę ocenę pogłębić. Jaki dokładnie charakter miał ów rewizjonizm? Jakie są jego dystynktywne cechy na tle innych nurtów polskiej, poststalinowskiej filozofii marksistowskiej? Wszak był to przez kilka dekad nurt w polskiej filozofii marksistowskiej dominujący.

1 Tomasz Czakon, „Ocena marksizmu w Polsce”, w: Współczesna filozofia społeczna w Polsce: wybrane problemy, red. Tomasz Czakon, Danuta Ślęczek-Czakon (Katowice: „Śląsk”, 2014).

2 Andrzej Walicki, „Marksistowska filozofia w PRL w świetle osobistych wspomnień”, Przegląd Filozoficzny 16, 3 (2007): 247-276, tu 270. 


\section{Trzy „rewizjonistyczne” tradycje polskiego marksizmu: marksizm humanistyczny, marksizm analityczny i marksizm scjentystyczny}

Termin rewizjonizm w tradycji marksistowskiej niejedno ma imię. Z jednej strony może oznaczać odrzucenie (zrewidowanie) istotnych filozoficznie tez samego Karola Marksa i Fryderyka Engelsa na rzecz innych, jak uczynił to na przełomie XIX i XX wieku Eduard Bernstein. Może też oznaczać odrzucenie kardynalnych założeń dominującej w danych czasach wersji marksizmu w celu restytucji „oryginalnej” lub „prawdziwej” myśli samego Marksa, na przykład poprzez przeciwstawienie go jego epigonom czy nawet samemu Engelsowi, jak uczynił to w Polsce Stanisław Brzozowski, a na Zachodzie Karl Korsch czy Antonio Gramsci. Generalnie większość myślicieli określanych tradycyjnie mianem rewizjonistów miała na celu racjonalizację (rozumianą potocznie jako „usprawnienie”) samej myśli marksistowskiej dla dobra ruchu socjalistycznego ${ }^{3}$. W interesującym nas kontekście rewizjonizmem zwykło się nazywać grupę nurtów filozoficznych odwołujących się do myśli młodego Marksa, które powstały po protestach i przemianach społeczno-politycznych w krajach tzw. realnego socjalizmu po 1956 roku. Oponowały one przeciwko panującej wówczas dogmatycznej interpretacji filozofii marksistowskiej4. Dogmatyzm ów można za Janem Woleńskim zdefiniować jako założenie, że marksizm dysponuje wystarczającą aparaturą pojęciową i narzędziami, by poradzić sobie $z$ każdym problemem filozoficznym ${ }^{5}$. W podobnym sensie rozpatruję prace badawcze pochodzące ze szkoły scjentystycznej - jako próbę oddzielenia pewnych idei materializmu dialektycznego od stalinowskiego

3 Zob. np. Marcin Niemczyk, „Rewizjonizm jako przejaw racjonalizacji myśli socjalistycznej", Annales Universitatis Mariae Curie-Skłodowska Lublin - Polonia Sectio G 66, 1 (2019): 331-348.

4 Krzysztof Brzechczyn, „Rewizjonizm w Polsce - dziwaczny bękart przemian politycznych w 1956 roku”, Filo-Sofija 32, 1 (2016): 123-137.

${ }^{5}$ Jan Woleński, „From Controlled Liberalism to Real Pluralism. The Development of Philosophy in Poland at the End of the Communism Era", w: 20 Years After the Collapse of Communism, red. Nicolas Hayoz i in. (Bern: Peter Lang, 2011), 567. 
dogmatyzmu i uzgodnienia ich $\mathrm{z}$ aktualnym stanem wiedzy naukowej i dominującymi w owych czasach trendami w filozofii naukowej.

Przed rozpoczęciem bardziej szczegółowych rozważań warto najpierw wstępnie sklasyfikować główne nurty polskiej filozofii marksistowskiej powstałe w wyniku popaździernikowej „odwilży” i scharakteryzować najważniejsze pozycje filozoficzne przez nie zajmowane:

1. Marksizm humanistyczny. Ów nurt zazwyczaj uznaje się za reprezentatywny typ rewizjonizmu w marksizmie w podanych wyżej znaczeniach. Określenia „marksistowski humanizm” i „marksistowski rewizjonizm” w obiegu filozoficznym są używane niemal jako synonimy. Rewizjonizm ten kojarzony jest w Polsce głównie z Warszawską Szkołą Historyków Idei, którą zakładali Bronisław Baczko, Leszek Kołakowski i Jerzy Szacki. Jej tradycja miała swoich wybitnych kontynuatorów w osobach wspomnianego Andrzeja Walickiego, Marka Siemka, Ryszarda Panasiuka, Zbigniewa Kuderowicza i innych. Rewizjonizm „,humanistyczny”, najkrócej ujmując, oznaczał odrzucenie stalinowskiej, historycystycznej teleologii oraz rehabilitację kantowskiej filozofii transcendentalnej i próbę pogodzenia jej z tezami Marksa. W rezultacie wszelkie poznanie miało mieć charakter społeczny (intersubiektywny), miało znosić klasyczny podział na poznający podmiot i poznawany przedmiot, przy czym historia miała dowodzić, że poznanie zawsze ma charakter cząstkowy, niepełny. Marksistowski humanizm odżegnywał się od ukształtowanego $\mathrm{w}$ stalinizmie materializmu dialektycznego z jego roszczeniami do naukowości i pełnej poznawalności świata. W aspekcie teoriopoznawczym humanizm marksistowski prezentował zatem stanowisko zasadniczo fenomenalistyczne ${ }^{6}$. Podobnie jak inne odmiany humanizmu marksistowskiego nurt ten podkreślał nadrzędność kategorii praktyki oraz aktywny charakter poznawczy działalności człowieka w świecie, co wypływało ze zrodzonych w trakcie „odwilży październikowej” nadziei na oddolną reformę systemu socjalistycznego. Z tradycją humanistyczną wiąże się rozwój problematyki antropologicznej i etycznej w marksizmie. Poza wspomnianą szkołą podejmowali ją również Adam Schaff, który omawiał problematykę egzystencjalistyczną w filozofii marksi-

6 Walicki, „Marksistowska filozofia w PRL”: 260. 
stowskiej, i Marek Fritzhand, który ufundował badania nad metaetyką $\mathrm{w}$ marksizmie.

2. Marksizm analityczny. Mówiąc najogólniej, jest to nurt marksizmu szeroko korzystający z narzędzi logiki formalnej i posługujący się analizą filozoficzną do rozpatrywania problemów marksizmu. Choć termin „marksizm analityczny” jest kojarzony z nurtem filozoficznym, który narodził się w latach siedemdziesiątych XX wieku w tradycji anglosaskiej (Gerald Cohen, John Roemer, Jon Elster, Adam Przeworski itd.), za jego właściwych protoplastów należy uznać właśnie wybranych polskich rewizjonistów, którzy pozostawali pod przemożnym wpływem badań logicznych prowadzonych w Szkole Lwowsko-Warszawskiej. Główną cechą dystynktywną polskiego marksizmu analitycznego była budowa logiki formalnej eksplikującej podstawowe pojęcia i problemy dialektyki materialistycznej. Próby takie zostały podjęte jeszcze w latach czterdziestych i pięćdziesiątych przez Stanisława Jaśkowskiego, Leonarda Rogowskiego i Romana Suszkę?. Badania te były kontynuowane w kolejnych dekadach przez grupę metodologów z Poznania z Leszkiem Nowakiem i Jerzym Kmitą na czele, który to zespół i jego współpracowników od lat siedemdziesiątych zaczęto określać mianem Poznańskiej Szkoły Metodologicznej. Reprezentanci tej szkoły wyróżniali się przede wszystkim afirmacją koncepcji semantycznych i metodologicznych Kazimierza Ajdukiewicza i nawiązaniem do hipotetyzmu Karla Poppera ${ }^{8}$.

Swoistym wyróżnikiem tej odmiany „rewizjonizmu” było utożsamienie marksizmu wyłącznie z filozofią samego Karola Marksa, do tego rekonstruowaną na wzór zachodniej, analitycznej filozofii nauki. Na gruncie tych prac przedstawiciele Szkoły Poznańskiej wykazywali, że myśl Marksa różni się zasadniczo od innych teorii humanistycznych i zawiera szereg wartościowych idei, głównie metodologicznych i teoriopoznawczych $^{9}$. Zespół badawczy pod przewodnictwem Leszka Nowaka stworzył ostatecznie oryginalną filozofię nauki odwołującą się do pierwotnych

7 Leszek Nowak, „Marksizm dzisiaj”, Przegląd Filozoficzny 16, 3 (2007): 283-292.

8 Krystyna Zamiara, „U początków poznańskiej szkoły metodologicznej”, w: Filozofia na Uniwersytecie w Poznaniu, red. Tadeusz Buksiński (Poznań: Wydawnictwo UAM, 2010).

9 Tamże. 
intuicji badawczych samego Marksa i z tych pozycji odrzucał dogmaty oficjalnego marksizmu.

3. Scjentystyczna szkoła filozofii marksistowskiej. Przedstawiciele tego nurtu, będącego głównym przedmiotem niniejszego artykułu, zajmowali się przede wszystkim problematyką metodologiczną, ontologiczną i epistemologiczną marksizmu, starając się jego stanowiska na tym gruncie zmodernizować czy właśnie zrewidować poprzez nawiązania do teorii i metodologii nauk w wydaniu neopozytywistycznym. Przedstawiciele tego nurtu cenili w neopozytywizmie analizę semantyczną i analizę struktury nauki, natomiast krytykowali go za wąski empiryzm, redukcjonizm i ahistoryczne podejście do nauki ${ }^{10}$. Istotnym wyróżnikiem tej szkoły, w przeciwieństwie do orientacji humanistyczno-antropologicznej, jest fakt, że „scjentyści” koncentrowali się przede wszystkim na samym materializmie dialektycznym, odcinając się od stanowiącej problematyki historiozoficznej, ekonomicznej i społeczno-politycznej, która w ich przekonaniu stanowiła rdzeń marksizmu i wzbudzała najwięcej kontrowersji. Kierunek ów rozwijali Helena Eilstein, Władysław Krajewski, Zdzisław Augustynek, Stefan Amsterdamski, Irena Szumilewicz, Stanisław Butryn i inni. Grupa ta przechodziła ewolucję, zbliżając się z biegiem lat coraz bardziej do anglosaskiej filozofii analitycznej i filozofii nauki, jednocześnie samą dialektykę materialistyczną redukując do „ogólnej teorii rozwoju”" Zainteresowanie analizą filozoficzną i wpływy Szkoły Lwowsko-Warszawskiej sprawiły, że wielu z tych badaczy podzielało niektóre poglądy i zainteresowania badaczy ze Szkoły Poznańskiej. Można mówić jednak o pewnych różnicach, które tworzą kryterium demarkacji między tymi dwiema szkołami marksizmu. Po pierwsze, „scjentyści”, zajmując się diamatem, odwoływali się nie tylko do Marksa, ale przede wszystkim do prac Engelsa i Lenina, uznając te postaci i wyrażane przez nie poglądy za pełnoprawne i wartościowe stanowiska $\mathrm{w}$ historii filozofii materialistycznej. Tak rozumianą filozofię marksistowską jako naukę o świecie jako całości traktowali jako

10 Władysław Krajewski, „Spory i szkoły w filozofii marksistowskiej”, w: Władysław Krajewski, Szkice filozoficzne (Warszawa: KiW, 1963), 17.

11 Władysław Krajewski, „Filozofia nauki w Polsce”, Studia Philosophiae Christianae 30, 2 (1994): 185-192. 
nawiązanie do starożytnej tradycji jońsko-demokrytejskiej w sensie zajmowania się ogólną teorią rzeczywistości ${ }^{12}$. Co za tym idzie, choć „scjentyści” podobnie jak przedstawiciele innych szkół badali kwestie metodologiczne i teoriopoznawcze, w odróżnieniu od pozostałych chronili i modernizowali marksistowską ontologię jako całościową wizję rzeczywistości opartą na materializmie przyrodniczym i dialektyce przyrody ${ }^{13}$.

\section{„Rewizja” ontologiczna}

Wulgarność oficjalnego marksizmu sprawiła, że co najmniej od lat pięćdziesiątych ubiegłego wieku większość nurtów rewizjonistycznych wobec stalinizmu rewizję tę rozpoczynała od odrzucenia jego naiwnego realizmu i sprowadzenia historii filozofii do walki między „idealizmem” a „materializmem", koncentrując się na zagadnieniach epistemologicznych i uznając je za główny problem marksizmu. Przedstawiciele humanistycznego „rewizjonizmu" w marksizmie krytykowali ontologiczną orientację marksistów ukierunkowaną na dialektykę przyrody i związany z tym materializm przyrodniczy. Baczko wskazywał, że Marks i Engels (przynajmniej początkowo) ograniczali zakres filozofii do historyzmu, a zainteresowania przyrodoznawcze Engelsa były samowolnym przekroczeniem tego programu ${ }^{14}$. Co więcej, wskazywał również na problemy ze stosowaniem dialektyki do rzeczywistości niehumanistycznej ${ }^{15}$.

Główną osią rozważań scjentystycznie zorientowanych marksistów na temat ontologii marksistowskiej były dyskusje dotyczące dość lapidarnej definicji materii ukutej przez Lenina: „Materia jest kategorią filozoficzną służącą do oznaczenia obiektywnej rzeczywistości, która dana jest człowiekowi we

12 Krajewski, „Spory i szkoły”, 18.

13 Władysław Krajewski, „O przedmiocie filozofii marksistowskiej”, w: Władysław Krajewski, Szkice filozoficzne (Warszawa: KiW, 1963).

14 Bronisław Baczko, „Kryptoproblemy i historyzm”, w: Bronisław Baczko, Człowiek i światopoglądy (Warszawa: KiW, 1965), 379-380.

15 Tamże, 387. 
wrażeniach"16. Uznano ją za definicję łączącą aspekty epistemologiczne i ontologiczne, w której jednak te pierwsze były dominujące ${ }^{17}$. Marksistowscy „scjentyści” dostrzegali słabe strony tej definicji: hipotetyczność, aprioryczne (dogmatyczne) założenie o istnieniu „obiektywnego świata” poza podmiotem i tautologiczność takiego pojęciowego ujmowania materii ${ }^{18}$. Przyjęli jednak, że w świetle rozwoju przyrodoznawstwa odkrywającego kolejne cechy i atrybuty materii możliwe jest doprecyzowanie pojęcia na gruncie ontologicznym, postulując przy tym jedność jej filozoficznego i fizycznego pojmowania ${ }^{19}$. W tym celu odwoływali się do wypowiedzi Engelsa, który implicite definiował materię jako „byt fizyczny”. Pojęcie to zostało doprecyzowane przez Helenę Eilstein jako dystrybutywny zbiór obiektów istniejących fizycznie ${ }^{20}$. Tego typu podejście do problemu materii było wśród materialistów dialektycznych dość powszechne. Wynikało to z autorytetu Lenina, który w swoich wypowiedziach wskazywał, że źródłem materializmu dialektycznego jest fizyka ${ }^{21}$. Dlatego też Eilstein kojarzyła materializm dialektyczny z neopozytywistycznym fizykalizmem Carnapa, czyli poglądem, że każde zdanie da się wyrazić w języku fizyki ${ }^{22}$. Rodziło to przekonanie, że da się w ten sposób wyeksplikować większość pojęć i kategorii diamatu. Nie naruszało to przy tym jego głównego założenia, czyli monizmu filozoficznego uznającego "materię" za jedyną substancję rzeczywistości. Zaczęto jednak opisywać jej cztery podstawowe atrybuty: zmienność, przestrzennoczasowość, prawidłowość, zdeterminowanie ${ }^{23}$. Powyższe rozumienie materii miało na celu wykazanie zbieżności intuicji Engelsa i Lenina z koncepcjami Tadeusza Kotarbińskiego i jego nominalistycznym reizmem i pansomatyzmem, według których wszystko

16 Włodzimierz Lenin, „Materializm a empirokrytycyzm”, w: Dzieła wszystkie, t. 18 (Warszawa: KiW, 1984), 119.

17 Władysław Krajewski, Współczesna filozofia naukowa. Metafilozofia i ontologia (Warszawa: WFiS UW, 2005), 101-102.

18 Stefan Amsterdamski, „Lenin i pojęcie materii”, w: Główne zagadnienia filozofii, t. 1, red. Władysław Krajewski (Warszawa: PWN, 1967), 48-53.

19 Stefan Amsterdamski, Helena Eilstein, „Pojęcie materii w literaturze marksistowskiej”, w: Jedność materialna świata, red. Helena Eilstein (Warszawa: KiW, 1961), 27.

20 Tamże, 14.

${ }^{21}$ Piotr Fiedosiejew, Dialektyka epoki współczesnej (Warszawa: KiW, 1969), 544-545.

${ }^{22}$ Helena Eilstein, „Przyczynek do koncepcji materii jako bytu fizycznego”, w: Jedność materialna świata, 122-126.

${ }^{23}$ Tamże, 19. 
oprócz „rzeczy”, jak „procesy”, „własności” itd., to nazwy pozorne, a zatem można było wówczas w zgodzie z Engelsem wnioskować, że istnieją tylko rzeczy - obiekty materialne ${ }^{24}$. Wywołało to sprzeciw i ataki ze strony bardziej ortodoksyjnych marksistów, takich jak Jarosław Ładosz, który oskarżał „scjentystów” w osobach Amsterdamskiego i Eilstein o idealizm metodologiczny (tzn. przyjęcie metodologii neopozytywistycznej) i stworzenie marksizmu reistycznego, który miał być $\mathrm{w}$ istocie eklektyzmem łączącym dwie różne tradycje filozoficzne ${ }^{25}$.

Zainteresowanie współczesną filozofią naukową prowadziło również do rewizji dwóch klasycznych tez diamatu. Po pierwsze, odrzucano założenie o nieskończoności czasu i przestrzeni, ponieważ kwestia ta nie powinna być rozstrzygana na gruncie filozofii, lecz kosmologii i fizyki, co zresztą było zgodne z opinią Lenina negującego możliwość obiektywnej prawdziwości tego typu tez. Filozofia miała ograniczać się do roli heurystycznej i metodologicznej. W zgodzie z Engelsem, Leninem i teorią względności Einsteina czasoprzestrzenna struktura materii miała stanowić jej atrybut, zatem czas miał oznaczać trwanie materii, a przestrzeń jej występowanie. W związku z tym pojęcia czasu i przestrzeni postrzegano jako hipostazy wyabstrahowane z pojęcia materii. Za dogmat uznano aprioryczne przyjmowanie Leninowskiej (właściwie Arystotelesowskiej) tezy o strukturalnej niewyczerpywalności materii, ponieważ odkrycia fizyki kwantowej mogą tezę tę podważyć, przy jednoczesnym uznaniu ,jakościowej wielorakości” zarówno na poziomie makro-, jak i mikroskopowym, co miało stanowić dowód na dialektyczną jedność świata mimo jego dostrzegalnej analitycznie różnorodności. Ściślej mówiąc, dialektyczna jedność świata miała polegać na jedności dystrybutywnego aspektu materii - wspólnej natury (atrybutów) wszystkich obiektów materialnych i rządzących nimi praw nauki, oraz holistycznego - względności wszelkiej izolacji i odrębności obiektów materialnych; świat w tej wizji to

24 Tamże, 85-87.

25 Jarosław Ładosz, Współczesne formy walki materializmu z idealizmem (Warszawa: KiW, 1965), 80-82. Generalnie ortodoksyjni marksiści uważali wszystkie stanowiska w sporze o powszechniki za anachroniczne i nieadekwatne, ponieważ ograniczały się do obszaru języka, podczas gdy marksiści przejęli od Hegla tezę, że powszechniki są jednością tego, co zmysłowe, i tego, co myślowe, jak również jednością tego, co jednostkowe, i tego, co ogólne. 
spójny kosmos, którego nie można podzielić na części niezależne ${ }^{26}$. Ogółem niezmiennym aksjomatem pozostało samo pojęcie materii jako „obiektywnej rzeczywistości”, czyli założenie, że rzeczywistość ta jest równoznaczna z wszelką rzeczywistością badaną naukowo. W późniejszych pracach materia stała się modelem idealizacyjnym, który był formalnie „pusty”, to znaczy zakładano, że szczegółowe określenie tego, co zawiera w sobie materia, jest historycznie zmienne i stanowi kumulację „na bieżąco” aktualizowanych rezultatów badań naukowych, dlatego też w odróżnieniu od definicji naukowych definicja filozoficzna musi mieć z konieczności ogólnikowy charakter ${ }^{27}$.

\section{Problemy teoriopoznawcze}

Począwszy od lat pięćdziesiątych, przedstawiciele „rewizjonizmu” humanistycznego w marksizmie krytykowali szereg epistemologicznych założeń tradycyjnego diamatu z punktu widzenia myśli młodego Marksa. Za esencję tej krytyki można uznać słynny esej Leszka Kołakowskiego - Karol Marks i klasyczna definicja prawdy. W jego ujęciu poznawany świat przyrodniczy miał być wytworem człowieka, gdyż wszelkie poznanie przedmiotowe zakłada najpierw istnienie aparatu poznawczego, a nie sumą „wrażeń zmysłowych" kopiowanych przez jego umysł i weryfikowalnych za pomocą kryterium skuteczności (praktyki) ${ }^{28}$. Poznawalna zdaniem humanistów była nie obiektywna rzeczywistość, ale historyczne wytwory subiektywnej, intelektualnej praktyki społecznej. Według Marksa miał istnieć tylko „świat dla nas”, przez co scjentystyczne założenia o weryfikowaniu na gruncie klasycznego pojmowania zgodności pojęć, sądów czy wrażeń z „obiektywnym” światem za pomocą kryterium praktyki były niezgodne $\mathrm{z}$ myślą Marksa i bliższe

26 Eilstein, „Przyczynek do koncepcji materii”, 90-92, 99, 111-112, 152-176. To rozumowanie podzielali też zasadniczo Zdzisław Augustynek i Irena Szumilewicz, autorzy innych esejów w cytowanej monografii.

${ }^{27}$ Adam Synowiecki, Byt i myślenie (Warszawa: KiW, 1980), 273.

28 Leszek Kołakowski, „Karol Marks i klasyczna definicja prawdy”, w: Leszek Kołakowski, Kultura i fetysze (Warszawa: PWN, 2010), 45-47, 52-54. 
pragmatyzmowi w rozumieniu Williama Jamesa ${ }^{29}$. Ponadto Baczko podkreślił, że „całościowy” punkt widzenia marksizmu nie uprawnia do przyznawania mu uprzywilejowanej pozycji epistemologicznej, gdyż inne tradycje również mogą mieć swój cenny wkład ${ }^{30}$. Za ogólny wniosek można uznać przeciwstawienie dojrzałego Engelsa młodemu Marksowi i negację istnienia „obiektywnego stosunku poznawczego" ${ }^{\text {31. }}$.

Właśnie obiektywność tego stosunku starali się obronić „scjentyści”, dowodząc, że założenia diamatu w tym względzie są niesprzeczne $\mathrm{z}$ obserwacjami „humanistów” i pokrywają się z optyką innych tradycji filozoficznych. Szczególną uwagę „scjentyści” zwracali na status epistemologiczny wrażeń i jakości zmysłowych. Modyfikowali oni diamat w duchu krytycznego realizmu, przekonując, że choć nie istnieje stosunek tożsamości między światem wrażeń zmysłowych a „światem rzeczy prawdziwych”, podejście czysto teoriopoznawcze i subiektywistyczne problemu tego nie rozwiązuje, ponieważ nie dostarcza żadnych informacji o stopniu subiektywności odbieranych wrażeń. Powinna to badać nauka, gdyż treść tych wrażeń zależna jest od struktury narządów zmysłowych; obiektywne własności poznawanych rzeczy zależne są z kolei od własności innych rzeczy i nie zależą od subiektywnych rzeczy ${ }^{32}$. Twierdzono przy tym, że traktowanie zjawisk psychicznych jako wtórnych wobec zjawisk fizycznych nie wyklucza badania ich społecznego uwarunkowania, jest to bowiem część szerszego uwarunkowania przyrodniczego ${ }^{33}$. Podkreślano też, że istnieją granice poznania wytyczane przez aktualny stan społecznej praktyki, w ten sposób afirmując aktywny i selektywny stosunek podmiotu do obiektywnej rzeczywistości ${ }^{34}$. Ogółem wśród „scjentystów” panowała zgoda co do tego, że umysł ludzki „kopiuje” jakości pierwotne (rozciągłość, masa, ruch). Nie wchodząc w szczegóły powyższych rozważań, można stwierdzić, iż próba reformy czy też obrony „teorii odbicia” polegała

29 Tamże, 66-67.

30 Baczko, „Kryptoproblemy i historyzm”, 400.

31 Bronisław Baczko, „Wokół problemów alienacji”, w: Bronisław Baczko, Człowiek i światopoglądy (Warszawa: KiW, 1965), 427, 463.

32 Zdzisław Cackowski, „Treść poznawcza wrażeń zmysłowych”, w: Główne zagadnienia filozofii, t. 2, red. Władysław Krajewski (Warszawa: PWN, 1966), 72-75.

33 Amsterdamski, Eilstein, „Pojęcie materii”, 12.

34 Zdzisław Kochański, „Poznanie jako subiektywne odbicie obiektywnej rzeczywistości”, w: Główne zagadnienia filozofii, t. 2, 65-69. 
przede wszystkim na zatarciu różnic między diamatem a innymi nowożytnymi i współczesnymi nurtami materialistycznymi w filozofii $\mathrm{z}$ uwagi na to, że wszystkie miały reprezentować różne warianty krytycznego realizmu i teorii odbicia, co oznaczało doszukiwanie się „dialektyki” w kierunkach uznawanych przez Engelsa i tradycję radziecką za „mechanistyczne”. W ten sposób materializm miał tworzyć jedną filozofię, w której Lenin i Engels występowali obok Kartezjusza, Galileusza, Hobbesa, Locke’a, Helmholtza, Spencera $\mathrm{i}$ innych.

Niepoślednią rolę $\mathrm{w}$ takim łączeniu diamatu $\mathrm{z}$ innymi scjentystycznymi orientacjami odgrywała oficjalna rehabilitacja logiki formalnej, a także osiągnięć Szkoły Lwowsko-Warszawskiej na tym polu. Po trwających w latach czterdziestych i pięćdziesiątych niezbyt udanych próbach stworzenia „logiki dialektycznej" (jako pewnej formy logiki wielowartościowej), za sprawą najpierw ogólnikowych deklaracji Adama Schaffa komentującego pracę Kazimierza Ajdukiewicza o zagadnieniu zmiany, a później bardziej szczegółowych wywodów Ładosza i Krajewskiego, logikę i metody analityczne uznano zgodnie za jeden z wartościowych elementów dialektycznej metodologii nauk i zalecano szerokie ich wykorzystanie jako narzędzia służącego do rozwijania dialektyki materialistycznej ${ }^{35}$.

W obszarze konkretnych badań ten logicystyczny zwrot sprawił, że główną specjalnością polskich marksistów-„,scjentystów” stała się teoria prawdy. Polegało to przede wszystkim na rozmaitych próbach uzgodnienia założeń marksizmu z klasyczną koncepcją prawdy w wydaniu Arystotelesa. Według krytycznych ocen sprowadzało się to zwykle do „uściślenia” klasycznej definicji za pomocą marksistowskich terminów, przykładowo - uznania prawdy za sąd lub zdanie zgodne z „obiektywną" rzeczywistością ${ }^{36}$. Próbowano łączyć tę koncepcję z pojęciem prawdy względnej, zakładając, że prawda jest jakimś rodzajem „przybliżonej” zgodności z rzeczywistością. Spośród przedstawicieli tej szkoły najbardziej krytyczna była Eilstein, która zauważyła, że próby

35 Zob. Władysław Krajewski, „Dialektyka marksistowska a logika formalna”, w: Władysław Krajewski, Szkice filozoficzne; Jarosław Ładosz, Wielowartościowe rachunki zdań a rozwój logiki (Warszawa: KiW, 1961).

${ }^{36}$ Zob. np. Adam Schaff, Z zagadnień marksistowskiej teorii prawdy (Warszawa: KiW, 1959); Karol Martel, Podstawowe zagadnienia marksistowskiej teorii poznania (Warszawa: KiW, 1963); Jarosław Ładosz, Materializm dialektyczny (Warszawa: PZWS, 1973). 
łączenia klasycznej koncepcji z koncepcją prawdy względnej owocują przyjęciem sądów będących w myśl klasycznej koncepcji fałszami ${ }^{37}$. „Scjentyści” mieli za to ambiwalentny stosunek do marksistowskiego pojęcia praktyki społecznej i tych, którzy akcentowali jej wyraźną rolę w procesie poznania bądź uznawali ją za główne kryterium prawdy, przezywali „praksistami” ${ }^{38}$.

Zakres praktyki jako kryterium prawdy próbowali ograniczyć Eilstein i Amsterdamski, stwierdzając, że stosuje się ona tylko do weryfikacji sądów w sensie logicznym. Krajewski próbował bronić tego kryterium w stosunku do wrażeń, podając przykład weryfikacji przez praktykę zjawiska fatamorgany na pustyni i powołując się przy tym na Ingardena mówiącego o możliwości poznania „prawdziwości dowolnego wyniku poznawczego" ${ }^{39}$. Pisał też o niej w wąskim sensie jako o możliwości falsyfikacji przez praktykę "pojęć idealizacyjnych" formułowanych w nauce, będących przybliżonymi desygnatami przedmiotów realnych, jak chociażby pojęcie „jednorodnego atomu” czy „czystego kapitalizmu” ${ }^{40}$. W tym aspekcie „scjentyści” wyraźnie zbliżyli się do Szkoły Poznańskiej, co zresztą potwierdza dialog i niekiedy bliska współpraca przedstawicieli obu nurtów. Stało się to na przełomie lat sześćdziesiątych i siedemdziesiątych, kiedy Leszek Nowak i jego współpracownicy pracowali nad idealizacyjną koncepcją nauki, dochodząc do wniosku, że koncepcja ta pokrywa się z założeniami metodologicznymi i epistemologicznymi zawartymi w Kapitale Marksa ${ }^{41}$. Krajewski i jego towarzysze zajmujący się raczej stereotypowym diamatem doszli do podobnych wniosków. Zaowocowało to, począwszy od lat siedemdziesiątych, dalszym rozwojem tych wątków i wzajemnej współpracy obu szkół. Przy czym Nowak szedł w epistemologii jeszcze dalej i odrzucał klasyczne pojęcie prawdy, wskazując, że na jej

37 Helena Eilstein, „O koncepcjach "prawdy względnej «", Studia Filozoficzne 2 (1963): $152-153$.

38 Romuald Łoziński, Problematyczność „prawdy” (Wrocław: WUWR, 1991), 48.

39 Władysław Krajewski, „Problem prawdziwości wrażeń i pojęć”, w: Władysław Krajewski, Szkice filozoficzne.

40 Tamże, 248; Łoziński, Problematyczność „prawdy”, 54.

${ }^{41}$ Zajmowanie się Marksem nie leżało w pierwotnych założeniach, lecz w miarę badań nad idealizacyjną teorią nauki rozpoznano, że metodologia Marksa pokrywa się z tą stosowaną przez Galileusza i innych wybitnych ludzi nauki. Zamiara, „U początków”, 285; Leszek Nowak, Wstęp do idealizacyjnej teorii nauki (Warszawa: PWN, 1977), 14-17. 
gruncie wszystkie twierdzenia idealizacyjne są „zgodne” z rzeczywistością ${ }^{42}$. $\mathrm{W}$ to miejsce zaproponował swoją własną koncepcję prawdy esencjalistycz$n e j$, biorąc za założenie wyjściowe maksymę Hegla, głoszącą, iż „prawda jest systemem", wobec czego ustalenie prawdziwości pojedynczych sądów faktualnych w izolacji jest niemożliwe ${ }^{43}$.

Do zbliżonych wniosków musiała dojść również część przedstawicieli obozu scjentystycznego, którzy zrezygnowali z prób zdefiniowania prawdy na gruncie diamatu, relegując problematykę epistemologiczną na grunt materializmu historycznego ${ }^{44}$, w domyśle zakładając, że jest ona rzeczą socjologii wiedzy. Inni jeszcze bardziej pogrążali się w rozwiązaniach neopozytywistycznych, kierując uwagę na przykład w stronę semantycznej definicji prawdy Tarskiego ${ }^{45}$. Ogółem po latach próby połączenia klasycznej i marksistowskiej teorii prawdy wraz z praktyką jako kryterium uznano za dość ogólnikowe i nieudane ${ }^{46}$. „Humaniści” zapewne trafnie je więc odrzucali, zauważając, że podział na świat podmiotu i świat przedmiotowy ma znaczenie głównie dla podkreślenia aktywnej roli podmiotu ludzkiego, który na drodze opanowywania i „przezwyciężania” świata rzeczy staje się podmiotem twórczym $^{47}$, kreującym kulturę i jej wartości.

${ }^{42}$ Leszek Nowak, „Klasyczna i esencjalistyczna koncepcja prawdy”, w: Odkrycie, abstrakcja, prawda, empiria, historia a idealizacja, red. Andrzej Klawiter, Leszek Nowak (Warszawa-Poznań: PWN, 1979).

${ }^{43}$ Leszek Nowak, Izabella Nowak, "Zasada wszechzwiązku i systemowość prawdy”, w: Odkrycie, abstrakcja, prawda, 126-141.

44 Zob. Jan Kurowicki, Poznanie a społeczeństwo (Warszawa: PIW, 1977).

45 Zob. Wacław Mejbaum, „Relacja korespondencji z punktu widzenia semantycznej teorii prawdy”, w: Zasada korespondencji w fizyce a rozwój nauki, red. Władysław Krajewski, Wacław Mejbaum, Jan Such (Warszawa: PWN, 1974).

46 Łoziński, Problematyczność „prawdy”, 118-124. Zob. Romuald Łoziński, Antysubiektocentryczna idea praktyki (Wrocław: WUWR, 1985).

47 Leszek Kołakowski, „Cogito, materializm historyczny, ekspresyjna interpretacja osobowości”, w: Leszek Kołakowski, Kultura i fetysze, 125. 


\section{Zwrot metodologiczny i rewizja „odwiecznych praw” dialektyki materialistycznej}

Spośród wszystkich wymienionych ostatecznym i najważniejszym wyróżnikiem scjentystycznej szkoły marksizmu pozostaje rewizja samego materializmu dialektycznego i zredukowanie ${ }^{48}$ jego zakresu do ogólnej metafilozofii i metodologii nauk otwartej na możliwość dialogu z zachodnią filozofią nauki. Metodologiczny zwrot „scjentystów” wydaje się znajdować uzasadnienie w wypowiedziach klasyków. Dowodzono, że w świetle poglądów Engelsa materializm dialektyczny stanowi pewną metafilozofię odrzucającą skrajny redukcjonizm, mechanicyzm, a przyjmującą dialektykę określającą ogólne prawa ruchu i rozwoju jako podstawową logikę (metodologię) nauk przyrodniczych $^{49}$. W związku z tym mniej istotna jest typowa dla stalinowskiego diamatu klasyfikacja praw i kategorii dialektycznych, najważniejsze zaś są idee, jakie za tym stoją ${ }^{50}$. Można je ogółem interpretować jako zalecenie, że niedopuszczalna jest taka procedura, która z twierdzeń filozoficznych dedukuje konkretne twierdzenie nauk szczegółowych lub też traktuje tezy filozoficzne jako kryterium prawdziwości tez naukowych. Chodziło o to, żeby problematyka materializmu dialektycznego była nasuwana przez naukę i przez nią też rozwiązywana, wobec tego jego problematyka filozoficzna jest problematyką teoretyczną nauk szczegółowych, co nie przekreśla sensowności diamatu ${ }^{51}$. W tym sensie stanowisko to było potwierdzeniem ocen formułowanych przez humanistycznych „rewizjonistów”. Kołakowski bowiem podobnie interpretował scjentyzm Engelsa - jako przepowiednię, że tradycyjnie rozumiana filozofia jest równoznaczna z idealizmem, zatem wraz z rozwojem nauki musi całkowicie zaniknąć, a jej rola musi zostać ograniczona do logiki formalnej i dialektyki, czyli szeroko rozumianej metodologii nauk ${ }^{52}$.

48 Wojciech Chudy, „Krótka historia marksistowskiego filozofowania w Polsce”, Ethos 33, 8 (1989): 259-277.

49 Stefan Amsterdamski, Engels (Warszawa: Wiedza Powszechna, 1965), 51-57.

50 Tamże, 58.

51 Tamże, 129-131.

52 Leszek Kołakowski, „Zakresowe i funkcjonalne rozumienie filozofii”, w: Leszek Kołakowski, Kultura i fetysze, 16. 
Nie oznacza to, że reprezentanci tej szkoły odrzucali inne sposoby filozofowania, w tym również te uprawiane przez marksistowskich „humanistów". Wyłanianie się różnych kierunków opartych na myśli Marksa i Engelsa uznano za coś całkowicie naturalnego, znajdującego potwierdzenie w historii rozwoju idei filozoficznych i naukowych. „Scjentystów” nie interesowała tylko przyroda, mieli jedynie postępować w zgodzie z dyrektywą Engelsa wskazującą, że filozofia powinna być uprawiana w sposób możliwie jak najbardziej ścisły i oparty na wynikach naukowych ${ }^{53}$. Przeciwstawianie Engelsa Marksowi uważano za niedopuszczalne, biorąc pod uwagę ich ścisłą i dobrze udokumentowaną współpracę. Różnice miały wynikać z podziału pracy, czego powodem była lepsza edukacja przyrodnicza Engelsa, po którego śladach podążał Marks ${ }^{54}$. W tym sensie zajęcie się przez „scjentystów” problematyką współczesnej filozofii nauki i metodologii było czymś postępowym z punktu widzenia takiej interpretacji filozofii Engelsa. Interesowali się oni anglosaską filozofią nauki w wydaniu Poppera, Kuhna, Feyerabenda, Lakatosa czy Laudana, jak również tradycją francuskiej filozofii nauki, chociażby w wydaniu Poincarégo, Le Roya i Duhema ${ }^{55}$.

Tak pojmowana materialistyczno-dialektyczna filozofia nauki prowadziła do odrzucenia dominującego w stalinowskim marksizmie skrajnego determinizmu i teleologicznej wizji historii, co można interpretować jako jego falsyfikację i uznanie antynaturalizmu metodologicznego w odniesieniu do teorii społecznej marksizmu. Odrzucono więc wertykalną, totalistyczną strukturę marksistowskiej filozofii dialektycznej, w której z rządzących kosmosem praw dialektyki przyrody miały wynikać prawa myślenia i rozwoju rzeczywistości społecznej, proponując w zamian strukturę horyzontalną, niuansując relacje między dialektyką przyrody, społeczeństwa i myślenia. Uznawano, że materializm dialektyczny genetycznie wywodzi się z historycznego. Oznacza to, że marksistowski „dogmat” o jedności materialnej świata odnosi się jedynie do człowieka, jego praktyki. Tak naprawdę mowa więc o „ludzkim świecie”;

53 Władysław Krajewski, Engels o ruchu materii i jego prawidłowości (Warszawa: KiW, 1973), 7.

54 Tamże, 8-22.

55 Twierdzenia Duhema były doceniane zwłaszcza w rozważaniach Jana Sucha nad zagadnieniem experimentum crucis w nauce. Jan Such, Problemy weryfikacji wiedzy (Warszawa: PWN, 1975), 106. 
obiektywność świata oznacza, że jest on „historyczno-subiektywny” ${ }^{56}$, zatem niekoniecznie mamy wgląd w świat sam w sobie, lecz go konstytuujemy poprzez społeczną, intersubiektywną praktykę poznawczą - co również jest zgodne $\mathrm{z}$ antynaturalizmem marksistowskiego humanizmu ${ }^{57}$. Ludzką historię postrzegano jednak jako część historii przyrody, jako jej szczególny przejaw, gdyż w zgodzie z Marksem ludzie i przyroda warunkują się wzajemnie. Dialektyka przyrody jest w tym sensie istotna, ponieważ badania z obszaru nauk szczegółowych, takich jak chociażby biologia, mogłyby pomóc wytłumaczyć historycznie zmienną naturę człowieka (czym interesował się sam Engels), zatem przyroda może być zasadnym przedmiotem refleksji jako jeden $\mathrm{z}$ determinantów kształtujących społeczeństwo ${ }^{58}$.

Zajmowanie się problematyką z zakresu filozofii nauki uzasadniano też nawiązaniami do stanowiska Engelsa. Według jego scjentystycznej interpretacji heglizmu wolność polegała na poznaniu praw przyrody i umiejętności posłużenia się zdobytą dzięki temu wiedzą do osiągania założonych celów i rozstrzygania problemów ${ }^{59}$. Spór między determinizmem a indeterminizmem polegający na tym, „czy dla każdego rodzaju znanych zdarzeń przyrody wskazać można takie parametry stanu odpowiedniego układu fizycznego, które jednoznacznie wyznaczają zajście albo niezajście zdarzenia określonego rodzaju"60, Amsterdamski proponował relegować z filozofii do nauk szczegółowych, jak fizyka czy biologia ${ }^{61}$. Generalnie on i pozostali „scjentyści” zgadzali się z intuicjami Engelsa i Lenina o niepewnym charakterze wszelkiego poznania i odrzucali ścisły determinizm w sensie ontologicznym ${ }^{62}$, uznając istnienie determinizmu statystycznego, o którym mówi się w kontekście badań w fizyce kwantowej ${ }^{63}$.

56 Amsterdamski, Engels, 25.

57 Kołakowski, „Zakresowe i funkcjonalne”, 30.

58 Tamże, 38-41.

59 Fryderyk Engels, Anty-Duhring (Warszawa: KiW, 1959), 112.

60 Stefan Amsterdamski, Zdzisław Augustynek, Wacław Mejbaum, Prawo, konieczność, prawdopodobieństwo (Warszawa: KiW, 1964), 89.

${ }^{61}$ Stefan Amsterdamski, Nauka a porządek świata (Warszawa: PWN, 1983), 183.

${ }^{62}$ Amsterdamski, Augustynek, Mejbaum, Prawo, konieczność, prawdopodobieństwo, 83, 114-115.

${ }^{63}$ Tamże, 96, 216. 
Dowodem istnienia takowego ma być występowanie w przyrodzie zdarzeń przypadkowych, które nie przeczą jej ogólnym prawidłowościom, wobec tego można je rozumieć jako pewną ogólną, statystyczną tendencję. Implikowało to konkluzję, że wolność można utożsamić z byciem niejednoznacznie zdeterminowanym, posiadaniem pewnego „luzu” i możliwością wyboru ${ }^{64}$. Takie rozumienie wolności i konieczności przytaczane w pracach „scjentystów” bywa określane mianem „umiarkowanego determinizmu”. Jest to stanowisko charakterystyczne dla różnych odmian poststalinowskiego marksizmu, tyle że „scjentyści” starali się je wyrazić w języku nawiązującym do nauk przyrodniczych.

Rewizji uległo także pojęcie rozwoju oraz problem obiektywności i konieczności praw dialektyki. Pojmowanie rozwoju jako zmiany postępowej implikującej konieczność występowania pewnych zdarzeń, w tym przechodzenia $\mathrm{z}$ „niższych” formacji społecznych do „wyższych”, miało być rezultatem uproszczonego, podręcznikowego rozumienia marksizmu. Tymczasem w ujęciu marksistowskich „scjentystów” rozwój to tyle co „zmiana kierunkowa”65. Proponowali oni, by pojmować rozwój jako „zmianę w ogóle”, co oznacza, że przyjmowali założenie o nieustannej zmianie wewnętrznej danego obiektu czy układu. O rozwoju rozumianym jako jednokierunkowa zmiana progresywna można było ich zdaniem mówić jedynie w odniesieniu do zjawisk przyrodniczych ${ }^{66}$. Krajewski zauważył, że Marks i Engels mówili co prawda, że przyrodą i społeczeństwem rządzą te same prawa, ale nie chodziło im o to, że prawa te są identyczne, ale o to, że prawa te są obiektywne ${ }^{67}$. Such rozwinął tę myśl, pisząc o dyrektywie historyzmu - zarówno zjawiska społeczne, jak i przyrodnicze mają charakter historyczny, wyłaniają się z nich nowe struktury o zupełnie nowych jakościach i rządzących nimi prawach, przy czym w przeciwieństwie do przyrodniczych generalizacje historyczne w odniesieniu do społeczeństwa często okazują się banalne ${ }^{68}$. Analogicznie

64 Amsterdamski, Nauka a porządek świata, 176. Autor przy tym krytycznie zastrzegał, że próby rozwiązania tego problemu w ramach „utopii komunistycznej” muszą oznaczać likwidację wolności, tamże, 172-175.

${ }_{65}$ Krajewski, Engels o ruchu, 119.

${ }^{66}$ Jan Such, Szkice o dialektyce (Warszawa: KiW, 1986), 16-20.

${ }^{67}$ Krajewski, Engels o ruchu, 289.

68 Such, Szkice o dialektyce, 23-25. 
Krajewski pisał, że w zgodzie z marksizmem prawa społeczne (prawa kapitalizmu) mają charakter przybliżony i statystyczny ${ }^{69}$. Nie są to więc prawa pozwalające formułować uniwersalne prognozy co do przyszłości całego systemu.

Ogółem w tym świetle prawidłowości materializmu dialektycznego nie są tożsame z prawami nauki, podlegającymi prawidłowościom historycznym. Mają charakter uniwersalny, filozoficzny (ontologiczny), co sprawia, że nie mogą być falsyfikowane. Pozwalają formułować tylko bardzo ogólne prognozy $^{70}$. Zasadniczo więc w ujęciu „scjentystów” determinizm dialektyczny sprowadza się do uznania jakościowego zróżnicowania praw nauki i podlegających im zjawisk przyrodniczych i społecznych oraz założenia o ich statystycznym charakterze ${ }^{71}$. W związku $\mathrm{z}$ tym scjentystycznie zorientowani marksiści woleli mówić raczej o zasadach materializmu dialektycznego niż przypisywać mu tworzenie praw analogicznych do praw nauki. Reasumując, na skutek scjentystycznej „rewizji” zadanie diamatu zostało zredukowane do obrony pewnych ogólnych dyrektyw metodologicznych ustanawiających swego rodzaju ideę regulatywną, wykluczającą możliwość stworzenia w oparciu o naukę ponadczasowej i mechanistycznej teorii niezmiennych praw rządzących rzeczywistością ${ }^{72}$.

Jest to wątek, w którym powyższa reinterpretacja założeń Engelsa i Lenina co do charakteru diamatu implicite pokrywa się z analizami Szkoły Poznańskiej dotyczącymi sposobu rozumienia dialektyki materialistycznej przez samego Marksa w jego pracach ekonomicznych. Chodzi tu przede wszystkim o osobę Leszka Nowaka, który w swoich analizach wykazał formalną sprzeczność między diamatem, zawierającym w jego ujęciu trafne naukowo założenia o zmiennym i dynamicznym charakterze rzeczywistości zarówno przedmiotowej, jak i podmiotowej, a hismatem, który miał zawierać „metafizyczne" założenia o stałej, dominującej roli sił wytwórczych w historii i co

69 Krajewski, Engels o ruchu, 360-362.

70 Such, Szkice o dialektyce, 190.

71 Tamże, 383-385.

72 Szerzej o materialistyczno-dialektycznej ontologii po odrzuceniu ograniczeń ideologicznych zob. Damian Winczewski, „Materializm dialektyczny po »diamacie«: naukowa ontologia dialektyczna i materializm przyrodniczy", Filozofia i Nauka 9, 1 (2021): 311-336. 
za tym idzie - o jednokierunkowym, liniowym charakterze jej rozwoju ${ }^{73}$. Główna różnica polega na tym, że o ile „scjentyści” zwykle w ogóle nie interesowali się hismatem, uznając go za konstrukt ideologiczny, o tyle Nowak przystąpił do konstruowania swojego oryginalnego, nie-Marksowskiego materializmu historycznego, przez co stał się jednym z najbardziej radykalnych krytyków oficjalnego marksizmu ${ }^{74}$.

\section{Zakończenie}

Uznaje się, że historia polskiego marksizmu w PRL na tle innych krajów poddanych ideologicznej i politycznej kurateli ZSRR była dość specyficzna i wyjątkowa. Po destalinizacji przeważająca część akademickich marksistów stała się w mniejszym lub większym stopniu rewizjonistami. Większość z nich starała się rozmywać oficjalną ideologię, a rytualne odniesienia do klasyków marksizmu ograniczyć do minimum ${ }^{75}$. O podobnej ewolucji można mówić w przypadku marksistowskich „scjentystów”. W latach pięćdziesiątych i sześćdziesiątych autorzy reprezentujący ten nurt dużo pracy poświęcili „scholastycznej” obronie materializmu dialektycznego polegającej na rewizji niektórych założeń i uzgodnieniu ich z wynikami nauk szczegółowych oraz trendami panującymi w filozofii neopozytywistycznej i analitycznej. W pozostałych dwóch dekadach trwania systemu w literaturze „scjentystycznej” odwołania do Engelsa i Lenina praktycznie zanikły, a większość autorów poświęciła się szczegółowym badaniom z zakresu filozofii i metodologii nauk, które były kontynuowane także po zmianie ustroju, potępiając ideologiczną stronę marksizmu, przy jednoczesnej afirmacji zachodniej filozofii analitycznej.

Ów stan rzeczy można tłumaczyć dwojako. Po pierwsze, autorytarną strukturą samego systemu i konformizmem ówczesnych marksistów, którzy podejmowali się obrony diamatu, by móc czerpać korzyści z pracy akademickiej

${ }^{73}$ Leszek Nowak, U podstaw dialektyki marksowskiej (Warszawa: PWN, 1977).

74 Waldemar Czajkowski, „Filozofia społeczna Leszka Nowaka w perspektywie historycznej i systematycznej”, Człowiek i Społeczeństwo 62 (2016): 53-72.

75 Walicki, „Marksistowska filozofia w PRL”: 267-268. 
i kontynuować pracę badawczą. Większość z nich pod koniec lat sześćdziesiątych nie miała już większych złudzeń co do systemu i odrzucała oficjalny czy "ortodoksyjny” marksizm. Niektórych przedstawicieli obozu scjentystycznego dotykały zresztą represje - w wyniku antysemickich czystek Marca '68 Eilstein została zmuszona do wyjazdu za granicę, Amsterdamski zaś stracił posadę na uczelni. Po powstaniu „Solidarności” wielu innych rzuciło legitymacją partyjną i zaangażowało się po stronie opozycji.

Czy jednak uprawianie marksistowskiego „scjentyzmu” można sprowadzić do presji systemowo-ideologicznej, historycznie warunkującej kierunek badań przedstawicieli tej szkoły? Taka ocena byłaby tylko kolejnym potwierdzeniem tezy Marksa o bycie kształtującym świadomość. Przegląd literatury z tamtego okresu i późniejszych wypowiedzi niegdysiejszych marksistów-„,scjentystów” świadczy o tym, że za taką, a nie inną ewolucją tej szkoły stoją również wewnętrzne przyczyny merytoryczne i teoretyczne. Próby tworzenia rozwiniętych systemów ontologicznych i epistemologicznych opartych na dialektyce materialistycznej uznano ostatecznie za dość ogólnikowe i nieudane. Nie poskutkowało to jednak odrzuceniem diamatu i negacją jego naukowego statusu na rzecz całkowitego przejścia do rozwiązań neopozytywistycznych i analitycznych. Reprezentanci tej szkoły podkreślali, że główne idee diamatu miały ważne znaczenie historyczne dla filozoficznych dyskusji o nauce i na stałe weszły do skarbnicy filozofii naukowej. Mimo braku bezpośrednich odniesień do klasyków marksizmu w literaturze metodologicznej późnego PRL, a także po transformacji ustrojowej główne dyrektywy metodologiczne diamatu były wciąż w użyciu ${ }^{76}$. Niektórzy, jak Krajewski, wskazywali często na wkład marksistów w rozwój nauki i trafne stanowiska diamatu

76 Można tu mówić między innymi o idei obiektywności badanego świata - zob. Stanisław Butryn, „Czynnik podmiotowy w idei ontologicznego realizmu naukowego”, Przegląd Filozoficzny 16, 3 (2007): 127-138, obronie monizmu materialistycznego - zob. Władysław Krajewski, „Naukowa filozofia przyrody”, w: Filozofia przyrody - dziś, red. Włodzimierz Ługowski, Igor K. Lisiejew (Warszawa: IFiS PAN, 2011), afirmacji dialektyki jako metody filozoficznej i naukowej - zob. Jan Such, Dialektyczne wizje świata (Warszawa-Poznań: PWN, 1992) czy obronie dialektycznej wizji kosmologii i koncepcji jakościowej nieskończoności materii (już bez dodawania, że jest „Leninowska”) - zob. Stanisław Butryn, „Has the Conception of the Quantum Origin of the Universe an Absolute Character?", Dialogue and Universalism 18, 12 (2008): 171-180. 
co do niektórych sporów w metafilozofii i filozofii nauki ${ }^{77}$. W pracach innych autorów, pomimo odcięcia się od marksizmu, także widoczny jest wpływ dialektycznych i naznaczonych historyzmem rozwiązań ${ }^{78}$. Można więc skonkludować, że historia marksistowskiego „scjentyzmu” w Polsce kończy się nie tyle jego obaleniem czy odrzuceniem, ile dialektycznym zniesieniem ${ }^{79}$, w którym najtrafniejsze założenia diamatu zostały wchłonięte przez współczesną, analityczną filozofię nauki.

\section{Bibliografia}

Amsterdamski Stefan. 1965. Engels. Warszawa: Wiedza Powszechna.

Amsterdamski Stefan. 1967. „Lenin i pojęcie materii”. W: Główne zagadnienia filozofi, t. 1, red. Władysław Krajewski, 48-60. Warszawa: PWN.

Amsterdamski, Stefan. 1983. Między historiq a metodą. Warszawa: PIW.

Amsterdamski, Stefan. 1983. Nauka a porzadek świata. Warszawa: PWN.

Amsterdamski Stefan, Helena Eilstein. 1961. „Pojęcie materii w literaturze marksistowskiej”. W: Jedność materialna świata, red. Helena Eilstein, 11-41. Warszawa: KiW.

77 Krajewski, Wspótczesna filozofia naukowa, 21-23, 32, 44, 58, 70, 84, 86, 88, 148.

78 Przykładem może być Amsterdamskiego koncepcja ideału nauki, która wydaje się łączyć filozofię nauki Thomasa Kuhna i wpływy materialistycznego historyzmu, pod postacią umiarkowanego antykumulatywizmu. Według autora pojęcie racjonalności jest historycznie uwarunkowanie i wartościujące. Reguły metodologiczne nie są uniwersalne, lecz zależne od akceptowanego ideału nauki, nie można wyróżnić nauki spośród jej tworów i innych typów działalności intelektualnej, kryteria demarkacji są zawodne i przestają działać po zmianie sytuacji. Profesjonalizacja i industrializacja nauki zaburzały jej autonomię, problematyzując jej racjonalność wywodzącą się z wartości kultury, w których wyrosła, sam rozwój nauki podważył koncepcję immanentnej ludzkiej racjonalności historycznej. Stefan Amsterdamski, Między historiq a metoda (Warszawa: PIW, 1983), 15-17, 26-27, 36-37, 128-129.

79 Samo pojęcie dialektycznego zniesienia zostało przekute przez radzieckich i polskich marksistowskich metodologów w regułę dialektycznej korespondencji, która zakłada, że w rozwoju nauki, kiedy mamy teorię T1 i T2, zawsze ex post okazuje się, że teoria T1 była teorią idealizacyjną nieuwzględniającą pewnych czynników ubocznych. Klasyczny przykład to mechanika klasyczna i kwantowa. Zob. Władysław Krajewski, „Redukcja, idealizacja, korespondencja”, w: Zasada korespondencji w fizyce a rozwój nauki, red. Władysław Krajewski, Wacław Mejbaum, Jan Such (Warszawa: PWN, 1973), 115-146. 
Amsterdamski Stefan, Zdzisław Augustynek, Wacław Mejbaum. 1964. Prawo, konieczność, prawdopodobieństwo. Warszawa: KiW.

Baczko Bronisław. 1965. „Kryptoproblemy i historyzm”. W: Bronisław Baczko, Człowiek i światopoglady, 373-419. Warszawa: KiW.

Baczko Bronisław. 1965. „Wokół problemów alienacji”. W: Bronisław Baczko, Człowiek i światopoglądy, 419-476. Warszawa: KiW.

Brzechczyn Krzysztof. 2016. „Rewizjonizm w Polsce - dziwaczny bękart przemian politycznych w 1956 roku”. Filo-Sofija 32: 123-137.

Butryn Stanisław. 2007. „Czynnik podmiotowy w idei ontologicznego realizmu naukowego". Przegląd Filozoficzny 16, 3: 127-138.

Butryn Stanisław. 2008. „Has the Conception of the Quantum Origin of the Universe an Absolute Character?". Dialogue and Universalism 18, 12: 171-180.

Cackowski Zdzisław. 1966. „Treść poznawcza wrażeń zmysłowych”. W: Główne zagadnienia filozofii, t. 2, red. Władysław Krajewski, 72-78. Warszawa: PWN.

Chudy Wojciech. 1989. „Krótka historia filozofowania marksistowskiego w Polsce”. Ethos 33, 8: 259-277.

Czajkowski Władysław. 2016. „Filozofia społeczna Leszka Nowaka w perspektywie historycznej i systematycznej”. Człowiek i Społeczeństwo 62: 53-72.

Czakon Tomasz. 2014. „Ocena marksizmu w Polsce”. W: Współczesna filozofia społeczna w Polsce: wybrane problemy, red. Tomasz Czakon, Danuta Ślęczek-Czakon, 76-111. Katowice: „Śląsk”.

Eilstein Helena. 1961. „Przyczynki do koncepcji materii jako bytu fizycznego”. W: Jedność materialna świata, red. Helena Eilstein, 42-204. Warszawa: KiW.

Eilstein Helena. 1963. „O koncepcjach "prawdy względnej«”. Studia Filozoficzne 2: 152-153.

Engels Fryderyk. 1959. Anty-Duhring. Warszawa: KiW.

Fiedosiejew Piotr. 1969. Dialektyka epoki współczesnej. Warszawa: KiW.

Kochański Zdzisław. 1966. „Poznanie jako subiektywne odbicie obiektywnej rzeczywistości”. W: Główne zagadnienia filozofii, t. 2, red. Władysław Krajewski, 54-71. Warszawa: PWN.

Kołakowski Leszek. 2010. „Cogito, materializm historyczny, ekspresyjna interpretacja osobowości”. W: Leszek Kołakowski, Kultura i fetysze, 82-130. Warszawa: Wydawnictwo Naukowe PWN.

Kołakowski Leszek. 2010. „Karol Marks i klasyczna definicja prawdy”. W: Leszek Kołakowski, Kultura i fetysze, 45-81. Warszawa: Wydawnictwo Naukowe PWN.

Kołakowski Leszek. 2010. „Zakresowe i funkcjonalne rozumienie filozofii”. W: Leszek Kołakowski, Kultura i fetysze, 14-44. Warszawa: Wydawnictwo Naukowe PWN. Krajewski Władysław. 1963. „Dialektyka marksistowska a logika formalna”. W: Władysław Krajewski, Szkice filozoficzne, 143-162. Warszawa: KiW. 
Krajewski Władysław. 1963. „O przedmiocie filozofii marksistowskiej”. W: Władysław Krajewski, Szkice filozoficzne, 22-40. Warszawa: KiW.

Krajewski Władysław. 1963. „Problem prawdziwości wrażeń i pojęç”. W: Władysław Krajewski, Szkice filozoficzne, 233-246. Warszawa: KiW.

Krajewski Władysław. 1963. „Spory i szkoły w filozofii marksistowskiej”. W: Władysław Krajewski, Szkice filozoficzne, 9-21. Warszawa: KiW.

Krajewski Władysław. 1973. Engels o ruchu materii i jego prawidłowości. Warszawa: KiW.

Krajewski Władysław. 1974. „Redukcja, idealizacja, korespondencja”. W: Zasada korespondencji w fizyce a rozwój nauki, red. Władysław Krajewski, Wacław Mejbaum, Jan Such, 115-146. Warszawa: PWN.

Krajewski Władysław. 1994. „Filozofia nauki w Polsce”. Studia Philosophiae Christianae 30, 2: 185-192.

Krajewski Władysław. 2005. Wspótczesna filozofia naukowa. Warszawa: WFiS UW.

Krajewski Władysław. 2011. „Naukowa filozofia przyrody”. W: Filozofia przyrody$d z i s ́$, red. Włodzimierz Ługowski, Igor K. Lisiejew, 28-32. Warszawa: IFiS PAN.

Kurowicki Jan. 1977. Poznanie a społeczeństwo. Warszawa: PIW.

Lenin Włodzimierz. 1984. „Materializm a empirokrytycyzm”. W: Włodzimierz Lenin, Dzieła wszystkie, t. 18. Warszawa: KiW.

Ładosz Jarosław. 1961. Wielowartościowe rachunki zdań a rozwój logiki. Warszawa: KiW.

Ładosz Jarosław. 1965. Wspótczesne formy walki idealizmu z materializmem. Warszawa: KiW.

Ładosz Jarosław. 1973. Materializm dialektyczny. Warszawa: PZWS.

Łoziński Romuald. 1985. Antysubiektocentryczna idea praktyki. Wrocław: WUWR.

Łoziński Romuald. 1991. Problematyczność „prawdy”. Wrocław: WUWR.

Martel Karol. 1963. Podstawowe zagadnienia marksistowskiej teorii poznania. Warszawa: KiW.

Mejbaum Wacław. 1974. „Relacja korespondencji z punktu widzenia semantycznej teorii prawdy". W: Zasada korespondencji w fizyce a rozwój nauki, red. Władysław Krajewski, Wacław Mejbaum, Jan Such, 281-298. Warszawa: PWN.

Niemczyk Marcin. 2019. „Rewizjonizm jako przejaw racjonalizacji myśli socjalistycznej”. Annales Universitatis Mariae Curie-Skłodowska Lublin - Polonia Sectio G 66, 1: 331-348.

Nowak Leszek. 1977. U podstaw dialektyki marksowskiej. Warszawa: PWN.

Nowak Leszek. 1977. Wstęp do idealizacyjnej teorii nauki. Warszawa: PWN.

Nowak Leszek. 1979. „Klasyczna i esencjalistyczna koncepcja prawdy”. W: Odkrycie, abstrakcja, prawda, empiria, historia a idealizacja, red. Andrzej Klawiter, Leszek Nowak, 115-125. Warszawa-Poznań: PWN.

Nowak Leszek. 2007. „Marksizm dzisiaj”. Przeglad Filozoficzny 16, 3: 283-292. 
Nowak Leszek, Izabella Nowak. 1979. „Zasada wszechzwiązku i systemowość prawdy". W: Odkrycie, abstrakcja, prawda, empiria, historia a idealizacja, red. Andrzej Klawiter, Leszek Nowak, 126-141. Warszawa-Poznań: PWN.

Schaff A. 1959. Z zagadnień marksistowskiej teorii prawdy. Warszawa: KiW.

Such Jan. 1974. „Relacja korespondencji a wynikanie”. W: Zasada korespondencji $w$ fizyce a rozwój nauki, red. Władysław Krajewski, Wacław Mejbaum, Jan Such, 65-114. Warszawa: PWN.

Such Jan. 1975. Problemy weryfikacji wiedzy. Warszawa: PWN.

Such Jan. 1986. Szkice o dialektyce. Warszawa: KiW.

Such Jan. 1992. Dialektyczne wizje świata. Warszawa-Poznań: PWN.

Synowiecki Adam. 1980. Byt i myślenie. Warszawa: KiW.

Walicki Andrzej. 2007. „Marksistowska filozofia w PRL w świetle osobistych wspomnień". Przegląd Filozoficzny 16, 3: 247-276.

Winczewski Damian. 2021. „Materializm dialektyczny po »diamacie«: naukowa ontologia dialektyczna i materializm przyrodniczy". Filozofia i Nauka 9, 1:311-336.

Woleński Jan. 2011. „From Controlled Liberalism to Real Pluralism. The Development of Philosophy in Poland at the End of the Communism Era". W: 20 Years After the Collapse of Communism, red. Nicolas Hayoz i in., 559-572. Bern: Peter Lang.

Zamiara Krystyna. 2010. „U początków poznańskiej szkoły metodologicznej”. W: Filozofia na Uniwersytecie w Poznaniu, red. Tadeusz Buksiński, 283-308. Poznań: Wydawnictwo UAM. 